\title{
Occult Hepatitis B Infection in Egyptian Chronic Hepatitis C Patients: Prevalence, Impact on Pegylated Interferon/Ribavirin Therapy
}

\author{
Mohamed H Emara ${ }^{*}$, Nahla E El-Gammal', Lamiaa A Mohamed², Maged M Bahgat ${ }^{1}$
}

\begin{abstract}
Background: Chronic HCV infection combined with occult hepatitis B infection has been associated with liver enzymes flare, advanced hepatic fibrosis and cirrhosis, poor response to standard interferon- $\alpha$, and increased risk of HCC. This study aimed to elucidate the prevalence of occult hepatitis B infection in Egyptian chronic HCV patients, and to clarify its role in non-response of those patients to pegylated interferon/ribavirin therapy. This study enrolled 155 consecutive chronic HCV patients under pegylated interferon/ribavirin therapy. All patients were exposed to clinical assessment, biochemical, histological and virological examinations. HBV parameters (HBV DNA, anti-HBc, anti-HBs) and patients' response status to the combination therapy were determined.

Results: In this study, occult hepatitis B infection occurs in 3.9\% of Egyptian chronic HCV patients; tends to affect younger age patients, associated with higher base line HCV viral load, less hepatic fibrosis than monoinfected patients. This occult hepatitis B infection is not a statistically significant cause of non-response to pegylated interferon/ribavirin therapy. Anti-HBs was not associated with any biochemical, histological or virological abnormalities in those patients, contrary to low response rate to therapy and higher HCV viral load that was observed with anti-HBC.
\end{abstract}

Conclusions: Detection of HBV DNA in HBsAg negative chronic HCV patients plays a non significant role in nonresponse of Egyptian patients to pegylated interferon/ribavirin therapy.

\section{Background}

Chronic hepatitis C (HCV) affects more than 170 million people worldwide, causing cirrhosis and liver cancer [1]. In Egypt, high HCV rates were reported reaching up to $20 \%$ [2]. The currently recommended therapy for chronic $\mathrm{HCV}$ is the combination of pegylated interferon alpha and ribavirin (Peg-IFN/RBV) that proved to be superior to standard interferon alpha and ribavirin [3]. More than $50 \%$ of patients can achieve a sustained virological response (SVR) after 24-48 weeks of this combination therapy, making $\mathrm{HCV}$ a potentially curable disease [1]. For patients with HCV genotype 4 infections (the prevalent genotype in Egypt), combination treatment with pegylated interferon alpha and weight based ribavirin administered for 48 weeks seems to be an

\footnotetext{
* Correspondence: emara_20007@yahoo.com

'Tropical Medicine Department, Faculty of Medicine, Zagazig University, Zagazig, Egypt

Full list of author information is available at the end of the article
}

appropriate regimen [4]. Occult hepatitis B virus infection (OBI) is defined as the presence of HBV DNA, in serum and/or the liver tissue without detectable HBsAg with or without anti-HBc or anti-HBs outside the preseroconversion window period [5]. Both $\mathrm{HBV}$ and $\mathrm{HCV}$ share common routes of transmission and hence there is a consensus that patients with chronic HCV liver disease, are at high risk of OBI [6,7]. OBI may contribute to liver inflammation through episodes of increased viral replication, increased immune activity and subsequent liver injury [8].

In chronic $\mathrm{HCV}$ infection, the presence of OBI has been associated with liver enzymes flare [8], increased severity of liver disease towards advanced fibrosis and cirrhosis $[6,9]$, poor response to standard interferon- $\alpha$ in many [6,9-12], but not all [13] studies, and increased risk of HCC $[14,15]$.

Although the potential mechanism for reduced interferon response in these cases remains unclear, one 
intriguing investigation has shown decreased intrahepatic expression of interferon receptor mRNA and protein in OBI [12].

Some studies suggested a negative influence of OBI on the response to standard interferon in chronic $\mathrm{HCV}$ infection [6,9-12]. This observation needs to be confirmed in HCV populations treated with the standard of care Peg-IFN/RBV combination therapy [16].

This study aimed to elucidate the prevalence of OBI in Egyptian chronic HCV patients, and to clarify its role as a cause of non-response of those patients to the standard of care Peg-IFN/RBV therapy.

\section{Patients and methods}

The ethical committee of our institution approved this study to be conducted at both Al-Ahrar General Hospital and Zagazig University Hospitals, Sharkia Governorate, Egypt, and included 155 chronic HCV patients under Peg-IFN/RBV therapy. The diagnosis of HCV was confirmed by detection of anti-HCV antibody and $\mathrm{HCV}$ RNA and they were all candidates to begin the combination therapy according to the guidelines of the national Committee for Control and Prevention of viral Hepatitis "C" in Egypt, with the following criteria:

\section{Inclusion criteria}

1. Age:18-60 years.

2. White blood cells $>4000 / \mathrm{mm}^{3}$

3. Neutrophils $>2000 / \mathrm{mm}^{3}$.

4. Platelets $>85000 / \mathrm{mm}^{3}$.

5. Prothrombin time $<2$ seconds above upper limit of normal (ULN).

6. Direct bilirubin $0.3 \mathrm{mg} / \mathrm{dl}$.

7. Indirect bilirubin $0.8 \mathrm{mg} / \mathrm{dl}$.

8. Albumin $>3.5 \mathrm{gm} / \mathrm{dl}$.

9. Serum creatinine, Fasting blood sugar, TSH within normal limits.

10. HBsAg: Negative.

11. ANA $<1: 160$.

12. Positive for anti-HCV and HCV RNA.

13. If diabetic, $\mathrm{HB} \mathrm{A} 1 \mathrm{C}<8.5 \%$.

14. Alpha feto-protein $<100 \mathrm{IU} / \mathrm{ml}$., but If is $>100$, C. $\mathrm{T}$. is normal.

15. Females practice adequate contraception.

16. Male patient's wife practicing adequate contraception.

17. Signed written informed consent for the study.

\section{Exclusion criteria}

Exclusion of,

1. Any other cause of chronic liver disease other than HCV (by liver biopsy).

2. Overt HBV Co-infection

3. Autoimmune disease (by ANA).
4. Alcoholic liver disease.

5. Decompensated liver disease.

6. Hypersensitivity to Peg-IFN/RBV.

7. Pregnancy or breast feeding.

8 . Poorly controlled diabetes.

9. Clinically significant retinal abnormalities.

10. Obesity -induced liver disease.

11. Drug-induced liver disease.

12. CNS trauma or active seizures which requires medication

13. Ischemic cardiovascular insult within the last 6 months.

14. Immunologically mediated diseases.

15. Patients with organ transplant.

16. Substance abuse (abstention for the last 12 months).

17. Immunosuppressive drugs.

18. Severe pre-existing psychiatric conditions.

\section{Patients}

In this cross sectional study, patients were divided into two groups according to their HBV DNA status:

Group I: Patients having HBV DNA positivity (dually infected patients).

Group II: Patients negative for HBV DNA (moninfected patients).

All the studied patients were subjected to the following:

I-Clinical assessment

History taking, BMI, physical examination.

\section{Biochemical assessment}

Liver function tests, kidney functions, complete blood counts, serum uric acid, cholesterol and triglycerides, HCV RNA both pre-enrollment and during treatment were examined.

\section{Liver biopsy}

Pathological examination performed at liver histopathology laboratory, Faculty of Medicine, Zagazig University. More than one pathologist revised the slides to minimize inter-observer variability that commonly affects explanation of liver biopsy. Liver biopsies were paraffin-embedded and stained with haematoxylin-eosin and Masson trichrome stains, additional stains were used when needed. The biopsies were reviewed blindly without knowledge of any parameter. Hepatitis grading and staging were evaluated according to the METAVIR scoring system [17].

\section{Serodiagnosis of HBV}

anti-HBc total antibodies were detected by a rapid immunoassay (Gold Colloidal Conjugate Membrane, Cal-Tech Diagnostics, INC.- California, USA) while anti-HBs antibodies were determined by the electrochemi-luminescence immunoassay "ECLIA" technique using commercially available kits (Cobas e 411 analyzer, Hitachi, Japan). 


\section{HBV DNA examination}

The assay (done while the patients were under Peg-IFN/ RBV therapy) and results were performed and interpreted by investigators who were blinded to the patients' baseline characteristics, HBV serology and stage of liver biopsy. We used $\mathrm{COBAS}^{\odot}$ AmpliPrep/COBAS ${ }^{\odot}$ TaqMan $^{\oplus}$ HBV Test (Roche Diagnostics, Switzerland), which is a real time quantitative PCR technology. Specimen processing carried out by COBAS AmpliPrep analyzer, specimens were collected by professional staff with sticking to quality standards to avoid any potential contamination, blood was collected in EDTA containing tubes, transfer of the specimen within the laboratory was maintained at $2-8^{\circ} \mathrm{C}$, most samples were analyzed on the same day, while when stored for no more than 3 days, they were kept at room temperature $\left(25-30^{\circ} \mathrm{C}\right)$. The concentration of HBV DNA in EDTA-plasma that can be detected with a positivity rate of greater than $95 \%$ is $12 \mathrm{IU} / \mathrm{mL}$ or lower while its specificity is $100 \%$.

\section{Treatment regimens and follow up}

The dose of peginterferon is given subcutaneously around the umbilicus once per week, the dose of alpha2a is $180 \mathrm{ug}$ together with ribavirin, using $1000 \mathrm{mg} /$ day for those $\leq 75 \mathrm{~kg}$ in weight and $1200 \mathrm{mg} /$ day for those $>75 \mathrm{~kg}$ in weight; while the dose of alph-2b is $1.5 \mathrm{ug} / \mathrm{kg}$ body weight together with ribavirin at dose of $800 \mathrm{mg} /$ day for those weighting $<65 \mathrm{~kg} ; 1000 \mathrm{mg}$ for those $>65$ $\mathrm{kg}$ to $85 \mathrm{~kg} ; 1200 \mathrm{mg}$ for those $>85 \mathrm{~kg}$ to $105 \mathrm{~kg}$; and $1400 \mathrm{mg}$ for those $>105 \mathrm{~kg}$.

\section{Patient Monitoring}

All the patients attended to the Viral Hepatitis outpatient Clinic for monitoring during treatment. Patients were assessed at weeks 0, 1, 2 and 4 of treatment and thereafter monthly. At each review, laboratory tests were performed including serum ALT and AST, bilirubin, full blood count, and serum creatinine. Body weight and symptom checklist were recorded at each visit and dose modifications to the Peg-IFN or ribavirin were made when appropriate. Quantitative serum HCV-RNA was determined at baseline and at week 12. Qualitative HCV-RNA was determined at weeks 24 and 48 .

\section{Statistical analysis}

Data were checked, entered and analyzed using SPSS version 13 for data processing and statistics.

\section{Results}

The base line characters of all patients are described in (table 1). Out of the 155 examined chronic HCV patients, only 6 patients (3.9\%) had OBI. Comparison between OBI/HCV dually infected and HCV monoinfected patients showed that, dually infected patients are
Table 1 Characters of the studied patients.

\begin{tabular}{|c|c|c|}
\hline Number & \multicolumn{2}{|c|}{155} \\
\hline \multicolumn{3}{|l|}{ Age(years) } \\
\hline$X^{-} \pm S D$ & \multicolumn{2}{|c|}{$41.8 \pm 9.2$} \\
\hline Range & \multicolumn{2}{|c|}{ 19-59 } \\
\hline \multicolumn{3}{|l|}{ Sex } \\
\hline M & 125 & $80.6 \%$ \\
\hline $\mathrm{F}$ & 30 & $19.4 \%$ \\
\hline \multicolumn{3}{|l|}{ BMI } \\
\hline$X^{-} \pm S D$ & \multicolumn{2}{|c|}{$27.3 \pm 3.6$} \\
\hline Range & \multicolumn{2}{|c|}{$21-40.5$} \\
\hline \multicolumn{3}{|c|}{ Duration of HCV infection (years) } \\
\hline$X^{-} \pm S D$ & \multicolumn{2}{|c|}{$4.4 \pm 3.6$} \\
\hline Range & \multicolumn{2}{|c|}{ 1-19 } \\
\hline \multicolumn{3}{|c|}{ Smoking status } \\
\hline Non & 81 & $52.2 \%$ \\
\hline Active & 57 & $36.8 \%$ \\
\hline Ex-smoker & 17 & $11.0 \%$ \\
\hline \multicolumn{3}{|c|}{ Basal ALT $(\times$ ULN) } \\
\hline$\leq 2$ & 116 & $74.8 \%$ \\
\hline$>2$ & 39 & $25.2 \%$ \\
\hline \multicolumn{3}{|c|}{ Basal AST $(\times$ ULN) } \\
\hline$\leq 2$ & 124 & $80 \%$ \\
\hline$>2$ & 31 & $20 \%$ \\
\hline \multicolumn{3}{|l|}{ Activity } \\
\hline 1 & 52 & $33.6 \%$ \\
\hline 2 & 71 & $45.8 \%$ \\
\hline 3 & 32 & $20.6 \%$ \\
\hline \multicolumn{3}{|l|}{ Fibrosis } \\
\hline 1 & 54 & $34.8 \%$ \\
\hline 2 & 61 & $39.4 \%$ \\
\hline 3 & 36 & $23.2 \%$ \\
\hline 4 & 4 & $2.6 \%$ \\
\hline \multicolumn{3}{|c|}{ Basal HCV Viral Load $\left(I U \times 10^{5}\right)$} \\
\hline$X^{-} \pm S D$ & \multicolumn{2}{|c|}{$3.87 \pm 5.7$} \\
\hline Range & \multicolumn{2}{|c|}{$0.001-22.3$} \\
\hline
\end{tabular}

younger in age 32.8 years $(\mathrm{p}=0.013)$, had less advanced hepatic fibrosis $(p=0.02)$, and higher base line HCV viral load $(p=0.006)$ than monoinfected patients. Whereas, sex, BMI, liver enzymes, histological activity, HBV serological markers and response rates to PegIFN/RBV were comparable between the two groups (table 2).

Anti-HBc was associated with higher base line $\mathrm{HCV}$ viral load $9.43 \times 10^{5} \mathrm{IU} / \mathrm{ml}(\mathrm{p}<0.001)$ and poor response to the combination therapy $(\mathrm{p}=0.018)$, while no relation to histological indices, liver enzymes, HBV DNA nor to Anti-HBs antibodies (table 3).

Anti-HBs was not associated with any demographic, biochemical, histological, serological parameter abnormality 
Table 2 Biochemical, pathological and virological parameters in HBV/HCV dually infected and HCV mono-infected patients.

\begin{tabular}{|c|c|c|c|c|c|c|}
\hline & \multicolumn{2}{|c|}{$\begin{array}{l}\text { Occult HBV/HCV Dual Infection } \\
\qquad(n=6)\end{array}$} & \multicolumn{2}{|c|}{$\begin{array}{l}\text { HCV Monoinfection } \\
(n=149)\end{array}$} & \multirow{2}{*}{$\begin{array}{c}\text { Test } \\
\text { t Test }\end{array}$} & \multirow[t]{2}{*}{$\mathbf{P}$} \\
\hline Age (years) & & & & & & \\
\hline$X^{-} \pm S D$ & \multicolumn{2}{|c|}{$32.8 \pm 6.3$} & \multicolumn{2}{|c|}{$42.2 \pm 9.1$} & 2.48 & $0.013^{*}$ \\
\hline Range & \multicolumn{2}{|c|}{$20-36$} & \multicolumn{2}{|c|}{$19-59$} & & \\
\hline Sex & No. & $\%$ & No. & $\%$ & $x^{2}$ & \\
\hline M & 6 & 100.0 & 119 & 79.9 & 0.49 & 0.48 \\
\hline $\mathrm{F}$ & 0 & 0.0 & 30 & 20.1 & & \\
\hline BMI & & & & & $\mathbf{t}$ Test & \\
\hline$X^{-} \pm S D$ & \multicolumn{2}{|c|}{$25.7 \pm 1.5$} & \multicolumn{2}{|c|}{$27.3 \pm 3.6$} & 1.1 & 0.27 \\
\hline Range & \multicolumn{2}{|c|}{$24-27.5$} & \multicolumn{2}{|c|}{$21-40.5$} & & \\
\hline Basal ALT $(\times$ ULN) & No. & $\%$ & No. & $\%$ & $x^{2}$ & \\
\hline$\leq 2$ & 6 & 100.0 & 112 & 75.2 & 0.83 & 0.36 \\
\hline$>2$ & 0 & 0.0 & 37 & 24.8 & & \\
\hline Basal AST $(\times$ ULN) & No. & $\%$ & No. & $\%$ & $x^{2}$ & \\
\hline$\leq 2$ & 4 & 66.7 & 122 & 81.9 & 0.16 & 0.68 \\
\hline$>2$ & 2 & 33.3 & 27 & 18.1 & & \\
\hline Activity & No. & $\%$ & No. & $\%$ & $x^{2}$ & \\
\hline 1 & 2 & 33.3 & 50 & 33.6 & 1.88 & 0.39 \\
\hline 2 & 4 & 66.7 & 67 & 44.9 & & \\
\hline 3 & 0 & 0.0 & 32 & 21.5 & & \\
\hline Fibrosis & No. & $\%$ & No. & $\%$ & $x^{2}$ & \\
\hline 1 & 0 & 0.0 & 54 & 36.2 & & \\
\hline 2 & 6 & 100.0 & 55 & 36.9 & 9.62 & $0.02^{*}$ \\
\hline 3 & 0 & 0.0 & 36 & 24.2 & & \\
\hline 4 & 0 & 0.0 & 4 & 2.7 & & \\
\hline Basal HCV Viral Load $\left(I U \times 10^{5}\right)$ & & & & & t Test & \\
\hline$X^{-} \pm S D$ & \multicolumn{2}{|c|}{$10.05 \pm 9.93$} & \multicolumn{2}{|c|}{$3.62 \pm 5.4$} & 2.74 & $0.006^{*}$ \\
\hline Range & \multicolumn{2}{|c|}{$0.4-22.3$} & \multicolumn{2}{|c|}{$0.001-22$} & & \\
\hline Anti-HBc & No. & $\%$ & No. & $\%$ & $x^{2}$ & \\
\hline Negative & 4 & 66.7 & 133 & 89.3 & 1.09 & 0.29 \\
\hline Positive & 2 & 33.3 & 16 & 10.7 & & \\
\hline Anti-HBs & No. & $\%$ & No. & $\%$ & $x^{2}$ & \\
\hline Negative & 6 & 100.0 & 131 & 87.9 & 0.07 & 0.79 \\
\hline Positive & 0 & 0.0 & 18 & 12.1 & & \\
\hline Response Rate & No. & $\%$ & No. & $\%$ & $x^{2}$ & \\
\hline Responder & 0.0 & 0.0 & 70 & 46.98 & 3.42 & 0.06 \\
\hline Non-responder & 6.0 & 100 & 79 & 53.02 & & \\
\hline
\end{tabular}

* Significant

nor to the response rates to combination therapy between positive and negative patients (table 4).

All dually infected patients were males $<40$ years of age, had F2 hepatic fibrosis, A1-2 histological activity, all were non-responders to combination therapy, and 2 patients had HCV viral load at time of examination higher than the base line levels (table 5).

\section{Discussion}

The incidence of OBI in HCV patients varies greatly, ranging from $0 \%-52 \%[9,11]$, in this study the incidence of OBI is $3.9 \%$ (only 6 cases of detectable serum HBV DNA with mean HBV DNA level of $1726.2 \mathrm{IU} / \mathrm{ml}$ ) this low prevalence is in agreement with the rates reported by many investigators [18-20].

Our study, like many other studies, examined only one serum sample, which may not be sufficient to detect OBI if the viral replication is intermittent, and this together with the assumption that OBI is sensitive to Peg-IFN therapy and the intermediate prevalence of HBV in Egypt, 2-8\% HBsAg carrier rate [21], may account for the low prevalence of OBI in this study. 
Table 3 Anti-HBc status among studied patients.

\begin{tabular}{|c|c|c|c|c|c|c|}
\hline \multirow{3}{*}{ Age (years) } & \multicolumn{4}{|c|}{ Anti $\mathrm{HBC}$} & \multirow[t]{2}{*}{ Test } & \multirow[t]{2}{*}{$P$} \\
\hline & \multicolumn{2}{|c|}{$\begin{array}{l}\text { Positive } \\
(n=18)\end{array}$} & \multicolumn{2}{|c|}{$\begin{array}{l}\text { Negative } \\
(n=137)\end{array}$} & & \\
\hline & & & & & $\begin{array}{c}t \\
\text { Test }\end{array}$ & \\
\hline$X^{-} \pm S D$ & \multicolumn{2}{|c|}{$43.4 \pm 9.1$} & \multicolumn{2}{|c|}{$41.6 \pm 9.2$} & 0.79 & 0.43 \\
\hline Range & \multicolumn{2}{|c|}{ 28-59 } & \multicolumn{2}{|c|}{ 19-59 } & & \\
\hline Sex & No. & $\%$ & No. & $\%$ & $x^{2}$ & \\
\hline M & 16 & 88.9 & 109 & 79.6 & 0.39 & 0.53 \\
\hline $\mathrm{F}$ & 2 & 11.1 & 28 & 20.4 & & \\
\hline Activity & No. & $\%$ & No. & $\%$ & $x^{2}$ & \\
\hline 1 & 2 & 22.15 & 50 & 36.5 & & \\
\hline 2 & 12 & 66.7 & 59 & 43.1 & 5.02 & 0.08 \\
\hline 3 & 4 & 22.15 & 28 & 20.4 & & \\
\hline Fibrosis & No. & $\%$ & No. & $\%$ & $x^{2}$ & \\
\hline 1 & 4 & 22.2 & 49 & 35.7 & & \\
\hline 2 & 6 & 33.3 & 56 & 41.0 & 5.55 & 0.13 \\
\hline 3 & 8 & 44.4 & 28 & 20.4 & & \\
\hline 4 & 0 & 0.0 & 4 & 2.9 & & \\
\hline $\begin{array}{l}\text { Basal HCV Viral Load }(\mathrm{IU} \times \\
\left.\qquad 10^{5}\right)\end{array}$ & & & & & $\begin{array}{c}t \\
\text { Test }\end{array}$ & \\
\hline$X^{-} \pm S D$ & 9.43 & \pm 9.9 & 3.1 & \pm 4.5 & 4.66 & $\begin{array}{c}< \\
0.001^{*}\end{array}$ \\
\hline Range $\times 10^{5}$ & 0.62 & $2-22.3$ & 0.00 & $01-21$ & & \\
\hline Basal $\mathbf{A L T}(\times \cup L N)$ & No. & $\%$ & No. & $\%$ & $x^{2}$ & \\
\hline$\leq 2$ & 14 & 77.8 & 102 & 74.5 & 0.001 & 0.98 \\
\hline$>2$ & 4 & 22.2 & 35 & 25.5 & & \\
\hline Basal AST (× ULN) & No. & $\%$ & No. & $\%$ & $x^{2}$ & \\
\hline$\leq 2$ & 16 & 88.9 & 108 & 78.8 & 0.48 & 0.49 \\
\hline$>2$ & 2 & 11.1 & 29 & 21.2 & & \\
\hline HBV DNA & No. & $\%$ & No. & $\%$ & $x^{2}$ & \\
\hline Positive & 2 & 11.1 & 4 & 2.9 & 1.09 & 0.29 \\
\hline Negative & 16 & 88.9 & 133 & 97.1 & & \\
\hline Response Rate & No. & $\%$ & No. & $\%$ & $x^{2}$ & \\
\hline Responder & 4 & 22.2 & 66 & 48.2 & 5.58 & $0.018^{*}$ \\
\hline Non-responder & 14 & 77.8 & 71 & 51.8 & & \\
\hline Anti-HBs & No. & $\%$ & No. & $\%$ & $x^{2}$ & \\
\hline Positive & 4 & 22.2 & 14 & 10.2 & 1.22 & 0.26 \\
\hline Negative & 14 & 77.8 & 123 & 89.8 & & \\
\hline
\end{tabular}

* Significant

OBI is characterized by low serum HBV DNA, usually $<200 \mathrm{IU} / \mathrm{ml}$ and recent definitions of OBI included liver HBV DNA positivity as a prerequisite for considering OBI [16], but examination of liver tissue is not always applicable in clinical practice [20,22], and that is why highly sensitive PCR assays with low detection limit should be used in diagnosis of OBI [23]. In this aspect Levast et al., (2010) [22] reported liver tissue HBV DNA in 5 out of $113(4.4 \%)$ chronic $\mathrm{HCV}$ and none had serum HBV DNA. If occurrence of OBI is thought to be due to strong inhibition HBV replication by the immune
Table 4 Anti-HBs status among studied patients.

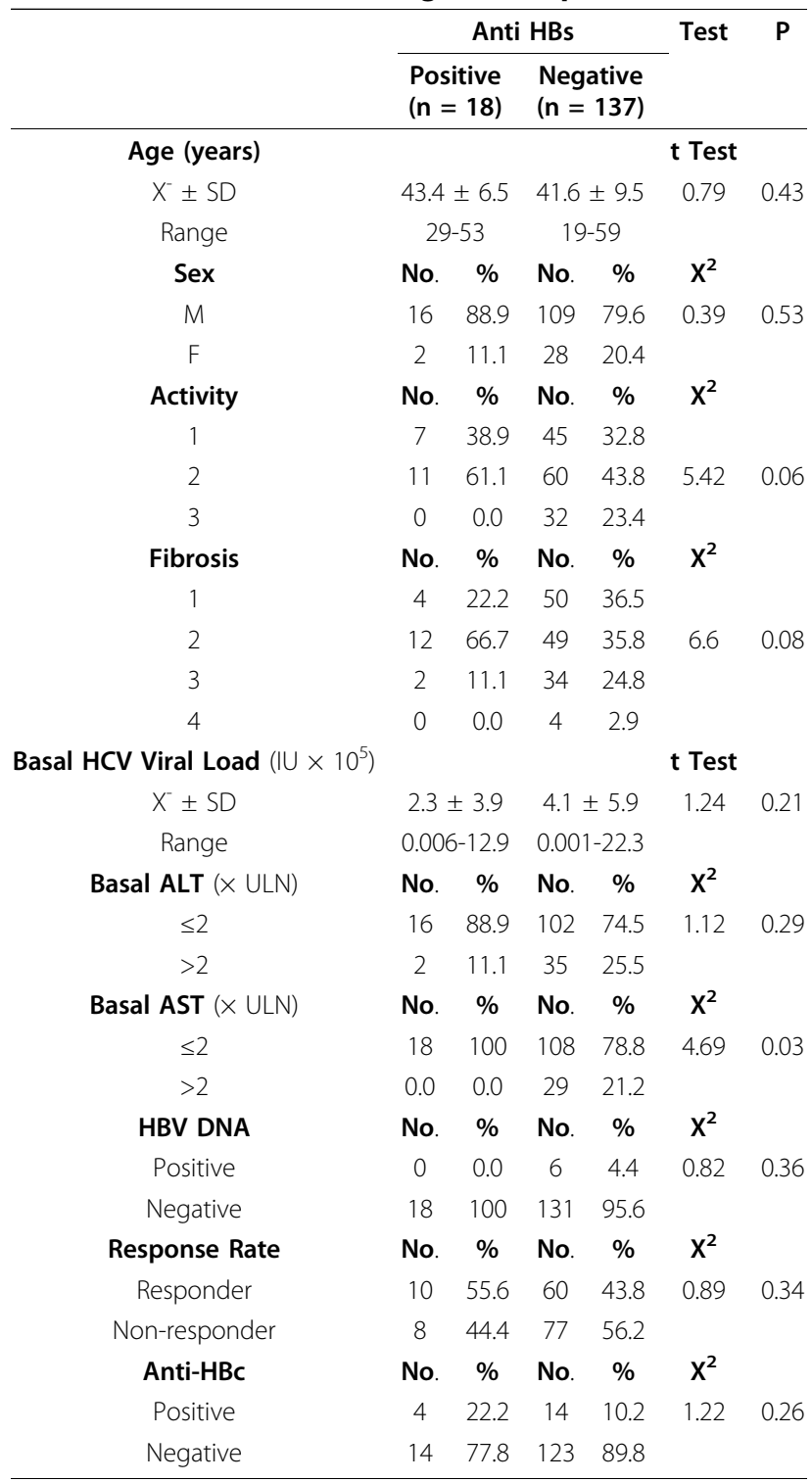

system, it thus would be expected to find low levels of HBV DNA in positive cases and this may explain their results [22].

There is a reciprocal inhibition of replication between both $\mathrm{HBV}$ and $\mathrm{HCV}$, with dominance of $\mathrm{HCV}$ inhibitory effect on HBV replication by its core protein [24], therefore $\mathrm{HBV}$ may flare up when the $\mathrm{HCV}$ virus is treated [25], and this may explain the slightly high levels of HBV DNA (> $2000 \mathrm{IU} / \mathrm{ml}$ ) reported in 4 cases of our study, although this is a possible explanation, yet it is not conclusive because we evaluated HBV DNA at only one point of time. If occurrence of OBI would be due to HBV surface mutants, that test negative for HBsAg by the commonly available commercial kits [26], and that may have levels of viraemia comparable to overt 
Table 5 Characteristics of the six HBV/HCV dually infected patients.

\begin{tabular}{|c|c|c|c|c|c|c|}
\hline Patient & 1 & 2 & 3 & 4 & 5 & 6 \\
\hline Age (years) & 20 & 36 & 21 & 37 & 35 & 34 \\
\hline Sex & M & M & M & M & M & M \\
\hline Baseline ALT $(\times \cup L N)$ & 1.5 & 1 & 1.5 & 1 & 1 & 1 \\
\hline Duration of HCV Infection (years) & 1 & 13 & 2 & 12 & 2 & 2 \\
\hline PostTreatment ALT (× ULN) & 1 & 1 & 1 & 1 & 0.5 & 0.5 \\
\hline COBAS HBV DNA Level $(\mathrm{IU} / \mathrm{ml})$ & 2980 & 2210 & 2880 & 2010 & 128 & 149 \\
\hline \multicolumn{7}{|l|}{ Serological Status } \\
\hline Anti-HBc & -ve & $+v e$ & -ve & +ve & -ve & -ve \\
\hline Anti-HBs & -ve & -ve & -ve & -ve & -ve & -ve \\
\hline \multicolumn{7}{|l|}{ METAVIR Score } \\
\hline Activity (A) & A2 & A2 & A2 & $\mathrm{A} 2$ & A1 & A1 \\
\hline Fibrosis (F) & $\mathrm{F} 2$ & $\mathrm{~F} 2$ & $\mathrm{~F} 2$ & F2 & F2 & $\mathrm{F} 2$ \\
\hline Basal HCV Load (IU/ml) & $0.4 \times 10^{5}$ & $22.3 \times 10^{5}$ & $0.39 \times 10^{5}$ & $22.1 \times 10^{5}$ & $7.2 \times 10^{5}$ & $7.23 \times 10^{5}$ \\
\hline Post-Treatment HCV Load (IU/ml) & $1.4 \times 10^{5}$ & $6 \times 10^{5}$ & $1.38 \times 10^{5}$ & $5.59 \times 10^{5}$ & $0.0028 \times 10^{5}$ & $0.027 \times 10^{5}$ \\
\hline Response to IFN & NR & NR & NR & $\mathrm{NR}$ & RR & RR \\
\hline
\end{tabular}

$M$, male, $F$, female. -ve, negative, +ve, positive, NR, non responder, RR, relapse

infection [27], it may be another explanation for the high serum HBV DNA levels in our study. Long lasting persistence of $\mathrm{HBV}$ in the liver may provoke a mild but continuing necroinflammation, that, if other causes of liver damage (such as $\mathrm{HCV}$ ) co-exist, may over time contribute to progression of chronic liver disease to cirrhosis $[8,28]$, this is shown in our patients where all dually infected patients were F2 and 4 cases were A2.

In this study OBI could not be predicted by serological markers of HBV infection, where only 2 out of the 6 patients with detectable HBV DNA had anti-HBc antibodies, and none had anti-HBs antibodies. Anti-HBc antibody was present in 18 patients with incidence of $11.6 \%$. Anti-HBc was associated with anti-HBs in 4 patients (2.6\%), while anti-HBc only state was reported in 14 patients $(9 \%)$. This can be explained by the notion that following HBV infection both anti-HBs and anti$\mathrm{HBc}$ antibodies develop, while titres of anti-HBs decreases over years to undetectable levels, anti-HBc antibodies only persists [29].

We reported non significant differences in histological activity and fibrosis between anti-HBc positive and negative patients and also between anti-HBc positive/ DNA positive and anti-HBc positive/DNA negative patients, these results disagree with Yuki et al. (2003) [30] and El-Sharaway et al. (2007) [31]. Our results are in agreement with those of Chen et al. (2010) [19] and Levast et al. (2010) [20], who reported lower and similar rates of histological activity and hepatic fibrosis between $\mathrm{OBI} / \mathrm{HCV}$ patients and HCV monoinfected patients respectively. These results seems not to be related to HCV genotypes, where our patients are mostly of genotype 4, that is known in Egypt to be extremely variable, not only in terms of sequence, but also in terms of functional and immunological determinants [32] in comparison to non-genotype 4 in their studies.

Anti-HBc is associated with higher basal HCV viral load and non-response to Peg-IFN/RBV therapy, but these findings needs to be confirmed in further studies, especially with the trend in the literature to neglect seromarkers of HBV in defining OBI.

Anti-HBs was not linked to non-response to IFN therapy in previous studies; this is also applied to our study, where no statistically significant difference as regard response rates to Peg-IFN based therapy was noticed. But, it should be evident that anti-HBs positive cases showed no correlation to advanced necroinflammation and fibrosis in our study, in contrast to what had been noticed by some authors [33].

As regard to impact of OBI on the response to standard interferon/ribavirin therapy, authers found a non significant results between patients with and without OBI [13,34-36]. In contrast low response rates were recorded in chronic HCV patients with OBI under standard interferon monotherapy [6,9-12]. Our study uses the standard of care Peg-IFN/RBV therapy, that potentially cures OBI. Levast et al., (2010) [20], conducted retrospective analysis of 140 patients treated for chronic HCV by Peg-IFN/RBV. They confirmed the lack of association between HBV markers (HBV DNA, anti-HBc, and anti-HBs antibodies) and disease severity or response to treatment, we reported similar findings for HBV DNA and anti-HBs while anti-HBc was linked to non-response to the combination therapy.

Chen et al., (2010) [19] concluded that, OBI was rare in $\mathrm{HCV}$, virological and biochemical features between $\mathrm{OBI} / \mathrm{HCV}$ patients and HCV monoinfection patients were comparable, these findings are similar to our 
findings, while HBV DNA in dually infected patients was low and patients with OBI responded to Peg-IFN/ RBV therapy, in contrast to high HBV DNA load in our patients and lack of response in our 6 patients, this may be related to HBV genotypes, where HBV genotype D is the prevalent genotype in Egypt.

Patients with $\mathrm{HCV} / \mathrm{HBV}$ dual infection were noticed to have high HCV RNA load than those with HCV mono-infection [11,37]. This seems to be applicable to genotype 4, where HBV DNA positive patients in our study showed higher baseline HCV viral load than HCV monoinfected patients. Suppression of the dominant virus - usually HCV predominates over HBV- may be associated with flares of the non-dominant virus, and this notion is reflected by the relatively high levels of HBV DNA in our positive cases $(1726.1 \mathrm{IU} / \mathrm{ml})$, in comparison to $200 \mathrm{IU} / \mathrm{ml}$ proposed by Raimondo et al. [16] and $923 \mathrm{IU} / \mathrm{ml}$ reported by Chen et al. [19], this may be related to viral genotypes where our cases are HCV genotype 4 and HBV genotype D whose clinical impact has been studied less extensively [38].

HBV DNA positive cases in our study tends to be of younger age group $(32.8 \pm 6.3$ years), this may be due to more risk of exposure to infection

\section{Conclusions}

In conclusion, detection of HBV DNA in HBsAg negative Egyptian chronic HCV patients is not a statistically significant cause of non-response of those patients to the current standard of care Peg-IFN/ribavirin therapy, and hence relying on the available data it is not currently recommended to screen for OBI in chronic HCV before initiation of antiviral therapy. The finding that anti-HBc antibody may be associated with non-response to antiviral therapy needs further confirmation. Anti-HBs seems to have no relation with any biochemical, pathological nor virological aspects in these patients. Dually infected patients are of younger age group, had higher baseline HCV viral load and were non responders to antiviral therapy.

\section{List of abbreviations}

A: Activity; BMI: Body Mass Index; F: Fibrosis; HBV: Hepatitis B Virus; HCC: Hepatocellular Carcinoma; HCV: Hepatitis C Virus; IU: International Unit; NR: Non-Responder; OBI: Occult Hepatitis B Infection; PEG-IFN: Pegylated Interferon; RBV: Ribavirin; RR: Relapser; SVR: Sustained Virological Response; ULN: Upper Limit of Normal.

\section{Acknowledgements}

The authors would thank Dr. Soha Elhawari and Dr. Mohamed Refaey for their kind help while conducting this work and for revising the draft of this manuscript. We hereby confirm that they had no conflict of interst.

\section{Author details}

${ }^{1}$ Tropical Medicine Department, Faculty of Medicine, Zagazig University, Zagazig, Egypt. ${ }^{2}$ Clinical Pathology Department, Faculty of Medicine, Zagazig University, Zagazig, Egypt.

\section{Authors' contributions}

MHE: participated in the study design planning, collection of cases, obtaining institutional and patients consent, and writing the manuscript, NEEG: participated in the study design planning, collection of cases, summarization of data and statistical analysis, LAM: participated in the study design planning, laboratory analyses including serology and DNA, and statistical analysis, MMB: participated in the study design planning, revision of patients' original records, obtaining institutional and patients consent, and writing the manuscript. All authors read, revised and approved this final manuscript.

\section{Competing interests}

The authors declare that they have no competing interests.

Received: 20 September 2010 Accepted: 17 November 2010 Published: 17 November 2010

\section{References}

1. Yuan $\mathrm{H}$, Lee W: Nonresponse to treatment for hepatitis C: current management strategies. Drugs 2008, 68:27-42.

2. Mohamed M: Epidemiology of HCV in Egypt. The Afro-Arab Liver journal 2004, 3:41-52

3. Hadziyannis SJ, Sette HJ, Morgan TR, Balan V, Diago M, Marcellin P, Ramadori G, Bodenheimer $H$, Bernstein D, Rizzetto M, Zeuzem S, Pockros PJ, Lin A, Ackrill AM, PEGASYS International Study Group: Peginterferon-alpha2a and ribavirin combination therapy in chronic hepatitis C: a randomized study of treatment duration and ribavirin dose. Ann Intern Med 2004, 140:346-355.

4. Derbala M, Amer A, Bener A, Lopez AC, Omar M, El Ghannam M: Pegylated interferon-alpha $2 \mathrm{~b}$-ribavirin combination in Egyptian patients with genotype 4 chronic hepatitis. J Viral Hepat 2005, 12:380-385.

5. Brechot $C$, Thiers $V$, Kremsdorf $D$, Nalpas $B$, Pol $S$, Paterlini-Brechot $P$ : Persistent hepatitis $B$ virus infection in subjects without hepatitis $B$ surface antigen: clinically significant or purely "occult"? Hepatol 2001, 34:194-203.

6. Cacciola I, Pollicino T, Squadrito G, Cerenzia G, Orlando M, Raimondo G: Occult hepatitis B virus infection in patients with chronic hepatitis $C$ liver disease. N Engl J Med 1999, 341:22-6.

7. Cacciola I, Pollicino T, Squadrito G, Cerenzia G, Villari D, de Franchis R, Santantonio T, Brancatelli S, Colucci G, Raimondo G: Quantification of intrahepatic hepatitis B virus (HBV) DNA in patients with chronic HBV infection. Hepatol 2000, 31:507-512.

8. Kannangai $R$, Vivekanandan $P$, Netski $D$, Mehta $S$, Kirk G, Thomasb $D$, Torbenson M: Liver enzyme flares and occult hepatitis B in persons with chronic hepatitis C infection. J Clinical Virol 2007, 39:101-105.

9. De Maria N, Colantoni A, Friedlander L, Leandro G, Idilman R, Harig J, Van Thiel D: The impact of previous HBV infection on the course of chronic hepatitis C. Am J Gastroenterol 2000, 95:3529-3536.

10. Zignego A, Fontana R, Puliti S, Monti M, Careccia G, Giannelli F, Giannini C, Buzzelli $G$, Brunetto MR, Bonino F, Gentilini P: Impaired response to alpha interferon in patients with an inapparent hepatitis $B$ and hepatitis $C$ virus coinfection. Arch Virol 1997, 142:535-544.

11. Fukuda R, Ishimura N, Niigaki M, Hamamoto S, Satoh S, Tanaka S, Kushiyama Y, Uchida Y, Ihihara S, Akagi S, Watanabe M, Kinoshita Y: Serologically silent hepatitis B virus coinfection in patients with hepatitis $C$ virus-associated chronic liver disease: clinical and virological significance. J Med Virol 1999, 58:201-207.

12. Fukuda R, Ishimura N, Hamamoto S, Moritani M, Uchida Y, Ishihara S, Akagi S, Watanabe M, Kinoshita Y: Co-infection by serologically silent hepatitis $B$ virus may contribute to poor interferon response in patients with chronic hepatitis $C$ by down-regulation of type-I interferon receptor gene expression in the liver. J Med Virol 2001, 63:220-227

13. Nirei K, Kaneko M, Moriyama M, Arakawa Y: The clinical features of chronic hepatitis $C$ are not affected by the coexistence of hepatitis $B$ virus DNA in patients negative for hepatitis B surface antigen. Intervirology 2000, 43:95-101.

14. Sheu J, Huang G, Shih L: Hepatitis C and B viruses in hepatitis B surface antigen-negative hepatocellular carcinoma. Gastroenterology 1992, 103:1322-1327.

15. Paterlini $P$, Driss $F$, Nalpas B, Pisi E, Franco D, Berthelot $P$, Brechot $C$ : Persistence of hepatitis $B$ and hepatitis $C$ viral genomes in primary liver 
cancers from $\mathrm{HBsAg}$-negative patients: A study of a low endemic area. Hepatology 1993, 17:20-29.

16. Raimondo G, Allain JP, Brunetto MR, Buendia MA, Chen DS, Colombo M, Craxi A, Donato F, Ferrari C, Gaeta GB, Gerlich WH, Levrero M, Locarnini S, Michalak T, Mondelli MU, Pawlotsky JM, Pollicino T, Prati D, Puoti M, Samuel D, Shouval D, Smedile A, Squadrito G, Trépo C, Villa E, Will H, Zanetti AR, Zoulim F: Statements from the Taormina expert meeting on occult hepatitis B virus infection. J Hepato 2008, 49:625-657.

17. Bedossa P, Poynard T, The French METAVIR Cooperative Study Group: An algorithm for grading activity in chronic hepatitis C. Hepatology 1996, 24:289-293.

18. Kattab E, Chemin I, Vuillermoz I, Vieux C, Mrani S, Guillaud O, Trepo C, Zoulim F: Analysis of HCV co- infection with occult hepatitis B virus in patients undergoing IFN therapy. J Clin Virol 2005, 33:150-157.

19. Chen LW, Chien RN, Yen CL, Chang JJ, Liu CJ, Lin CL: Therapeutic Effects of Pegylated Interferon Plus Ribavirin in Chronic Hepatitis C Patients with Occult Hepatitis B Virus Dual infection. J Gastroenterol Hepatol 2010, 25:259-263.

20. Levast M, Larrat S, Thelu MA, Nicod S, Plages A, Cheveau A, Zarski JP, Seigneurin JM, Mornad P: Prevalenc and Impact of Occult Hepatitis B Infection in Chronic Hepatitis C Patients treated with Pegylated Interferon and Ribavirin. J Med Virol 2010, 82:747-754.

21. Attia M: Prevalence of hepatitis B and C in Egypt and Africa. Antivir Ther 1998, 3:1-9.

22. Raimondo G, Pollicino T, Cacciola I, Squadrito G: Occult hepatitis B virus infection. J Hepatol 2007, 46:160-170.

23. Carreno V, Bartolome J, Castillo I, Quiroga J: Occult hepatitis B virus and hepatitis C virus infections. Rev Med Virol 2008, 18:139-157.

24. Shih C, Lo S, Miyamura T, Chen S, Lee Y: Suppression of Hepatitis B Virus Expression and Replication by Hepatitis C Virus Core Protein in HuH-7 Cells. J Virol 1993, 67:5823-5832.

25. European Association for the Study of the Liver EASL Clinical Practice Guidelines: Management of chronic hepatitis B. J Hepatol 2009, 50:227-242.

26. Zaaijer $H$, Torres $P$, Ontanon A, Ponte L, Koppelman M, Lelie $P$, van Hemert $F$, Boot $\mathrm{H}$ : Multiple surface antigen mutations in five blood donors with occult hepatitis B virus infection. J Med Virol 2008, 80:1344-1349.

27. Carreno V, Bartolome J, Castillo I, Quiroga J: Occult hepatitis B virus and hepatitis C virus infections. Rev Med Virol 2008, 18:139-157.

28. Giudice CL, Martinengo M, Pietrasanta P, Bocciardo L, Malavasi C, Rastelli S, Faraci M, Tripodi G: Occult hepatitis B virus infection: A case of reactivation in a patient receiving immunosuppressive treatment for allogeneic bone marrow transplantation. Blood Transfus 2008, 6:46-50.

29. Schifman RB, Rivers SL, Sampliner RE, Krammes JE: Significance of isolated hepatitis C core antibody in blood donors. Arch Intern Med 1993, 153:2261-2266.

30. Yuki N, Nagaoka T, Yamashiro M, Mochizuki K, Kaneko A, Yamamoto K, Omura M, Hikiji K, Kato M: Long-term histologic and virologic outcomes of acute self-limited hepatitis B. Hepatology 2003, 37:1172-1179.

31. El-Shaarawy A, Abdel Aziz M, Abdel Rahman S, Rageh E, El-Saharnouby A: HCV Genotype and "Silent" HBV coinfection: Two main risk factors for a more severe liver disease. Tanta Medi Sci I 2007, 2:15-26.

32. Zekri A, Bahnassy A, Ramadan A, El-Bassuoni M, Badran A, Madwar MA: Hepatitis $C$ genotyping versus serotyping in Egyptian patients. Infection 2001, 29:24-36.

33. Kato J, Hasegawa K, Torii N, Yamaguchi K, Hayashi N: A molecular analysis of viral persistence in surface antigen-negative chronic hepatitis $\mathrm{B}$. Hepatology 1996, 23:389-395.

34. Fabris P, Brown D, Tositti G, Bozzola L, Giordani MT, Bevilacqua P, de Lalla F, Webster GJ, Dusheiko G: Occult hepatitis B virus infection does not affect liver histology orresponse to therapy with interferon alpha and ribavirin in intravenous drug users with chronic hepatitis C. J Clin Virol 2004, 29:160-166.

35. Liaw YF, Chien RN, Lin SM, Yeh CT, Tsai SL, Sheen S, Chu CM: Response of patients with dual hepatitis $B$ virus and $C$ virus infection to interferon therapy. J Interferon Cytokine Res 1997, 17:449-452.

36. Hui C, Laub E, Wu H, Montob A, Kimb M, Lukd J, Lau G, Wright T: Fibrosis progression in chronic hepatitis $C$ patients with occult hepatitis $B$ coinfection. J Clin Virol 2006, 35:185-192.
37. Liu CJ, Chen PJ, Chen DS: Dual chronic hepatitis B virus and hepatitis C virus infection. Hepatol Int 2009, 3:517-525 [http://www.springerlink.com/ content/g8086332052jq5w6/fulltext.html], Published online: 8 August 2009. Asian Pacific Association for the Study of the Liver 2009.

38. El-Zayadi A: Hepatitis B Virus infection: The Egyptian Situation. Arab J Gastroenterol 2007, 8:94-98.

doi:10.1186/1743-422X-7-324

Cite this article as: Emara et al:: Occult Hepatitis B Infection in Egyptian Chronic Hepatitis C Patients: Prevalence, Impact on Pegylated Interferon/Ribavirin Therapy. Virology Journal 2010 7:324.

\section{Submit your next manuscript to BioMed Central and take full advantage of:}

- Convenient online submission

- Thorough peer review

- No space constraints or color figure charges

- Immediate publication on acceptance

- Inclusion in PubMed, CAS, Scopus and Google Scholar

- Research which is freely available for redistribution 